\title{
WOJSKOWY I CYWILNY TRANSPORT DROGOWY TOWARÓW NIEBEZPIECZNYCH ORAZ KADUNKÓW PONADGABARYTOWYCH
}

W artykule omówiono najważniejsze aspekty wojskowego i cywilnego transportu drogowego towarów niebezpiecznych i ładunków ponadgabarytowych. Przedstawione zostały podstawowe zasady przewozu ładunków ponadgabarytowych $i$ towarów niebezpiecznych. Scharakteryzowano parametry ładunków ponadgabarytowych oraz czynności przygotowawcze do przewozu takich ładunków. Omówione zostało oznakowanie sztuk przesylek oraz jednostki transportowej przewożacej towary niebezpieczne. Opisano obowiązowe wyposażenie jednostki transportowej przewożacej po drogach publicznych towary niebezpieczne.

\section{WSTĘP}

Transport jako gałaź gospodarki, należy do najszybciej rozwijających się dziedzin. W ostatnich latach cała logistyka wraz z transportem notuje największy postęp, zarówno w sferze stosowanych technologii i w sferze organizacyjno-planistycznej. Przewozy samochodowe sa aktualnie najbardziej popularnymi przewozami w procesach transportu i spedycji. Większość towarów przewozi się kontenerami, chodzi o drobnice i ładunki masowe zapakowane w worki i poukładane na paletach ładunkowych. Jednak obok tego rodzaju transportu uwagę należy zwrócić na przewozy towarów niebezpiecznych i ładunków ponadgabarytowych. Codziennie po polskich drogach poruszają się samochody przewożące towary niebezpieczne oraz zestawy ciagnikowe przewożące przedmioty bardzo ciężkie i ponadgabarytowe (rys.1). Transporty takie wymagaja przestrzegania szczegółowych przepisów regulujących takie przejazdy oraz zastosowania specjalistycznych środków transportu. Wykonywanie przewozów towarów niebezpiecznych oraz przewozów ponadgabarytowych jest złożonym procesem, który wymaga zaangażowania podmiotów biorących udział w procesie transportowym oraz znajomości przepisów krajowych i międzynarodowych. Zapewnienie bezpieczeństwa uczestnikom ruchu drogowego oraz maksymalne wyeliminowanie utrudnień wynikających $z$ warunków panujących na planowanej trasie przejazdu stanowi podstawę realizacji zadania przewozowego.

a)

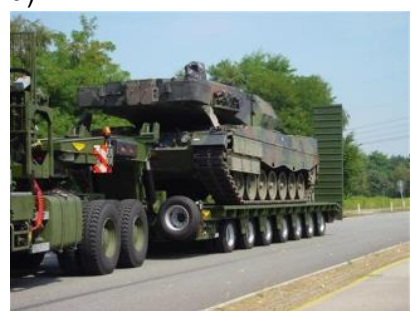

b)

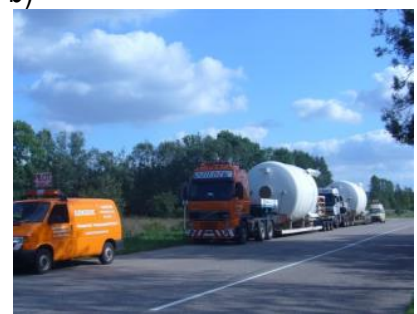

Rys. 1. Przykłady transportu ponadgabarytowego: a) wojskowy, b) cywilny

Źródło: zasoby własne

Zmieniająca się sytuacja militarna na świecie i w europie powoduje, że obserwujemy zwiększenie ilości przemieszczanego sprzętu wojskowego, w tym pojazdów przewożących ładunki po- nadgabarytowe (haubice, czołgi, maszyny inżynieryjne itp.) i towary niebezpieczne, w ramach ćwiczeń, szkoleń wojskowych lub do remontu i naprawy.

\section{WOJSKOWY I CYWILNY TRANSPORT PONADGABARYTOWY}

$\mathrm{Z}$ ładunkiem ponadnormatywny w transporcie drogowym mamy do czynienia wtedy, gdy jego waga lub wymiary (na długości, na szerokości lub na wysokości), przekraczają maksymalnie dopuszczalne parametry standardowego zestawu drogowego lub zestawu z przyczepa oraz dopuszczalne naciski na oś pojazdu.

Do ładunków ponadgabarytowych zaliczamy:

1. Ładunki dłużycowe - długość ładunku przekracza 1/3 lub więcej niż 2 metry długości powierzchni ładunkowej środka transportu.

2. Ładunki specjalne - wymiary geometryczne tego rodzaju ładunków przekraczają wymiary pojazdu.

3. Ładunki szczególnie ciężkie - masa ich przekracza ładowność środka transportu.

Transport tego rodzaju ładunków odbywa się za pomoca specjalnych środków transportu np. przyczep dłużycowych lub zestawów niskopodłogowych (rys.2).

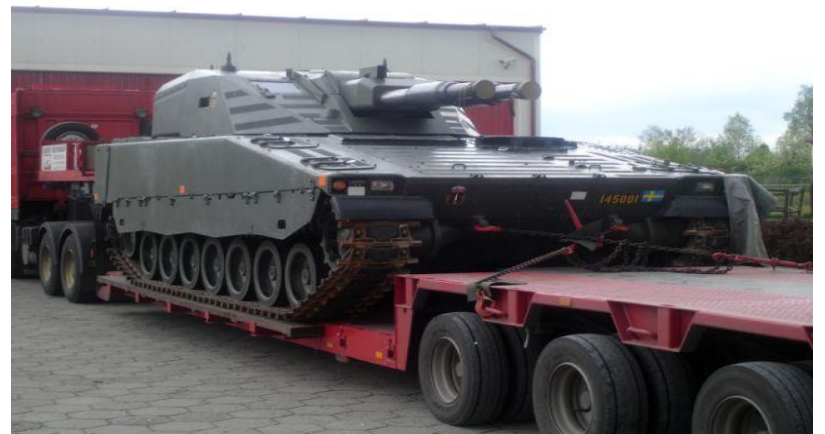

Rys. 2. Przykład transportu ponadgabarytowego pojazdu gąsienicowego z zastosowaniem zestawu niskopodwoziowego Źródło: zasoby własne

Do podstawowych czynności przygotowawczych transportu ponadnormatywnego należa:

1. Przygotowanie optymalnej i najkrótszej trasy przejazdu.

2. Uzyskanie zezwolenia na przejazd.

\section{AUTOBUSY 6/2018}


3. Sprawdzenie infrastruktury drogowej na trasie przejazdu.

4. Zapoznanie się z ładunkiem (masa, szerokość, wysokość).

5. Przygotowanie odpowiedniego środka transportowego do przewozu.

6. Wykonanie szczegółowego planu przewozu i postojów.

7. Ustalenie współpracy z niezbędnymi służbami i firmami biorącymi udział w planowanym przewozie.

Zgodnie z przepisami krajowymi [2] ruch pojazdu nienormatywnego po drogach publicznych jest dozwolony pod warunkiem uzyskania zezwolenia na przejazd pojazdu nienormatywnego odpowiedniej kategorii, wydawanego, w drodze decyzji administracyjnej, przez właściwy organ, a w przypadku pojazdu nienormatywnego należącego do $S Z R P$ pod warunkiem uzyskania zezwolenia wojskowego na przejazd drogowy, wydawanego przez właściwy organ wojskowy. Ponadto ruch takiego pojazdu odbywać się musi z zachowaniem warunków przejazdu określonych w zezwoleniu na przejazd, a w szczególnym przypadku pilotowania przejazdu pojazdu nienormatywnego przez pilotaże ze względu na jego wymiary lub masę. Za przekroczoną masę uważa się masę wynosząca powyżej $44 t$, natomiast, jeśli chodzi o wymiary transport ponadgabarytowy to taki, który przekracza:

- szerokość pojazdu - 2,55 m,

- długość zestawu z naczepa - 16,5 m,

- długość zestawu z przyczepa - 18,75 m,

- wysokość pojazdu - $4 \mathrm{~m}$.

Zasady organizacji i przewozów ładunków ponadgabarytowych zostały uregulowane zapisami prawnymi. Główne regulacje to Ustawa $[2,14]$.

Przejazdy zestawów ponadgabarytowych po drogach publicznych $w$ transporcie cywilnym wymagaja specjalnych zezwoleń Ustawa [2] określa kategorie zezwoleń I - VII, w zależności od rodzaju drogi oraz warunków przewozu. Zezwolenie wydaje zarządca drogi właściwy dla drogi, po której ruch ma być wykonywany. W przypadku przejazdów międzynarodowych takie pozwolenia musi wydać każdy kraj, przez który przejazd ma się odbyć. Każde państwo ma wyznaczone odpowiednie jednostki administracji publicznej, które wydają zezwolenia na przewóz ponadgabarytowy.

W Polsce urzędami wydającymi pozwolenia w zależności od rodzaju i czasu sa:

- Starosta właściwy dla danego obszaru,

- Generalny Dyrektor Dróg Krajowych i Autostrad (poprzez upoważnione jednostki organizacyjne),

- Naczelnik Urzędu Celnego.

Uzyskanie pozwolenia poprzedzone jest złożeniem wniosku, który zawierać powinien:

- wnioskodawce,

- przewoźnika,

- nadawcę,

- termin przejazdu,

- szczegółowe informacje o pojeździe,

- informacje o ładunku,

- dokładna trasę przejazdu.

Zezwolenie wydaje się dla podmiotu wykonującego przejazd pojazdem nienormatywnym, podając w nim:

a) okres ważności zezwolenia,

b) trasę przejazdu,

c) liczbę przejazdów,

d) pojazd, którym będzie wykonywany przejazd,

e) warunki przejazdu, łącznie $z$ dostosowaniem infrastruktury drogowej na trasie przejazdu,

f) sposób pilotowania, o ile jest ono wymagane.

W przypadku ładunków szczególnie ciężkich (w porównaniu ze standardową wytrzymałością dróg i mostów poszczególnych kate- gorii) lub o znacznych wymiarach (wysokość całkowita ponad 4,5 m, szerokość ponad 4,5 m) konieczne jest wyznaczenie trasy przejazdu przez odpowiednie władze administracyjne. Ze względu na termin wydawania decyzji administracyjnych $(14 \div 30$ dni) należy podjać czynności organizacyjne dla takie przejazdu co najmniej trzy tygodnie przed jej planowym terminem realizacji.

Na podstawie [2] przejazd kolumny pojazdów Sił Zbrojnych RP w skład której wchodzi więcej niż 5 pojazdów oraz ruch pojazdu nienormatywnego należącego do SZ RP , jest dozwolony pod warunkiem uzyskania zezwolenia wojskowego na przejazd drogowy, wydawanego przez właściwy organ wojskowy.

Organami wojskowymi uprawnionymi do wydawania zezwoleń wojskowych sa:

\section{Szef STiRW-CKRW}

- w przypadku przejazdów między obszarami odpowiedzialności RBLog i przejazdów poza granice kraju.

2. Szef WTiRW (Wydziału Transportu i Ruchu Wojsk) i HNS RBLog

- w przypadku przejazdów między obszarami odpowiedzialności WKTr i przejazdów na obszarze odpowiedzialności RBLog.

3. Komendant WKTr

- w przypadku przejazdów na obszarze odpowiedzialności WKTr.

Zezwolenia na przejazd drogowy w SZ wydaje się na jednorazowy przejazd, natomiast zezwolenia na przejazd drogowy w transporcie cywilnym wydawane są na:

a) Jednokrotny przejazd - zezwolenie ważne jest 14 dni,

b) Wielokrotny przejazd - zezwolenie ważne jest 30 dni.

Transport ładunków ciężkich i ponadgabarytowych odbywa się przeważnie porą nocna, kiedy natężenie ruchu jest mniejsze (rys.3,4)

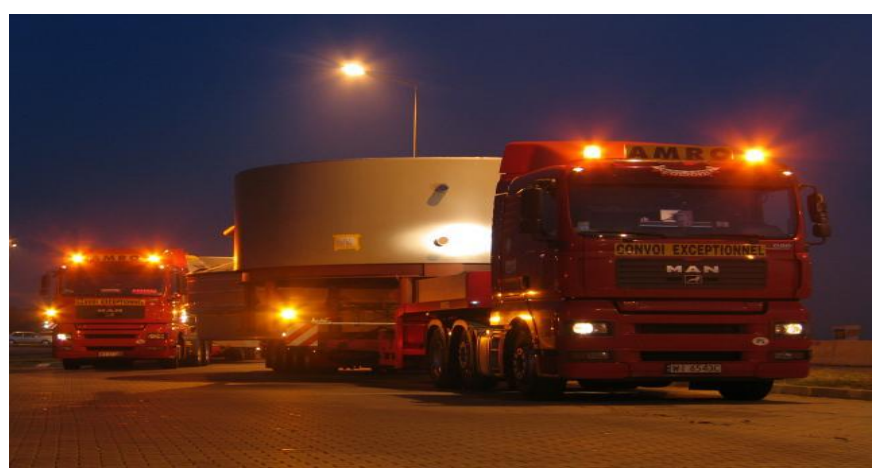

Rys. 3. Przejazd kolumny pojazdów nienormatywnych nocą z ładunkiem dla przemysłu destylacyjnego.

Źródło: gddkia.gov.pl [17].

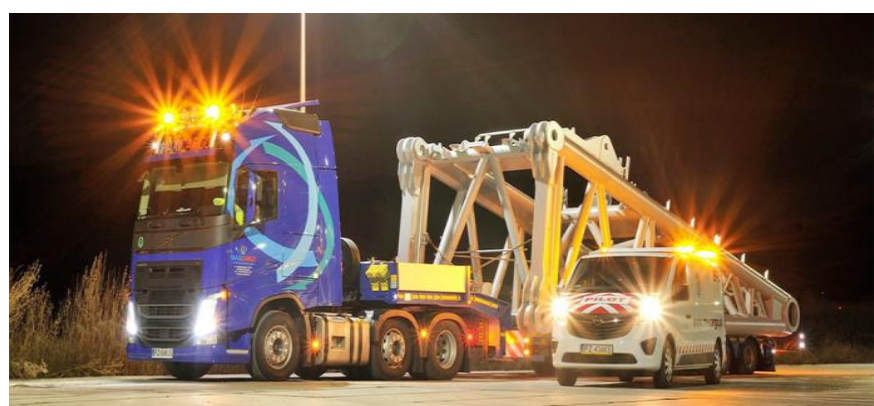

Rys. 4. Przejazd kolumny pojazdów nienormatywnych nocą z ładunkiem - konstrukcja stalowa.

Źródło: gddkia.gov.pl [17]. 
Specyfika przewozów ponadgabarytowych sprawia, że w czasie transportu tego rodzaju ładunków występują w Polsce liczne utrudnienia. Zaliczyć do nich należy: zły stan dróg, remonty, konieczność usunięcia elementów infrastruktury drogowej, ronda, wysepki na drodze.

\section{TRANSPORT TOWARÓW NIEBEZPIECZNYCH}

Przewóz towarów niebezpiecznych odbywa się na podstawie obowiazujacych aktów prawnych, jakimi sa: Ustawa o przewozie towarów niebezpiecznych [3], Umowa Europejska ADR [4], Ustawa prawo o ruchu drogowym [2]. W Siłach Zbrojnych RP dodatkowo obowiazuje: Rozporządzenie Ministra Obrony Narodowej [8]

w sprawie warunków krajowego przewozu towarów niebezpiecznych środkami transportu należącymi do Sił Zbrojnych RP lub środkami transportu, za które Siły Zbrojne RP są odpowiedzialne.

Zgodnie z przepisami ADR [4]: określenie „Towary niebezpieczne" oznacza materiały i przedmioty, których przewóz na podstawie ADR jest zabroniony albo dopuszczony wyłącznie na warunkach podanych w ADR.

Materiały niebezpieczne sa sklasyfikowane do jednej z 13 klas. Każdy ma przypisana własna pozycję oznaczona czteroliterowym numerem UN i jest przydzielony do jednej z trzech grup pakowania (GP). Informacje takie jak: (UN, nazwa wg ADR, klasa i grupa pakowania) są w zupełności wystarczające do identyfikacji każdego niebezpiecznego towaru.

Towary niebezpieczne to materiały i przedmioty, które ze względu na stwarzane przez nie zagrożenia dla ludzi i środowiska, moga być przewożone jedynie w określonych warunkach. Wskazać należy również na specyfikę towarów niebezpiecznych. Charakteryzują się one właściwościami, które w sposób nagły moga doprowadzić do niebezpiecznego zdarzenia. Najczęście będzie to pożar, poważne zatrucie ludzi lub środowiska, zniszczenie mienia czy śmierć ludzi i organizmów żywych. Z tego powodu warunki przewozu są bardzo ważne ze względu na bezpieczeństwo.

Celem przepisów regulujących przewóz towarów niebezpiecznych jest wyeliminowanie lub ograniczenie związanego z nim ryzyka poprzez zmniejszenie prawdopodobieństwa zaistnienia wypadku oraz rozmiaru ewentualnych szkód. Przepisy pozwalają na realizację przewozu w sposób maksymalnie bezpieczny poprzez zastosowanie efektywnych i sprawdzonych rozwiązań.

Uczestnicy przewozu_towarów niebezpiecznych powinni podejmować środki bezpieczeństwa odpowiednie do natury i zakresu dających się przewidzieć zagrożeń, w celu zapobieżenia szkodom i urazom oraz, jeżeli jest to wskazane, w celu zminimalizowania ich skutków. Uczestnicy przewozu powinni zawsze stosować się do odpowiednich wymagań umowy ADR.

W przypadku zaistnienia bezpośredniego zagrożenia bezpieczeństwa publicznego, uczestnicy przewozu powinni niezwłocznie powiadomić służby ratownicze oraz udostępnić im informacje potrzebne do prowadzenia działań.

Do uczestników przewozu zaliczamy:

- „Nadawcę” - przedsiębiorstwo, które wysyła towary niebezpieczne, zarówno we własnym imieniu jak też w imieniu osoby trzeciej. Jeżeli operacja transportowa odbywa się na podstawie umowy przewozu, to za nadawcę uważa się to przedsiębiorstwo, które jest nadawcą zgodnie z umową przewozu.

- „Przewoźnika” - przedsiębiorstwo, które wykonuje operację transportową na podstawie umowy przewozu lub bez niej.

- „Odbiorcę" - odbiorca zgodnie z umową przewozu. Jeżeli zgodnie z przepisami dotyczącymi umowy przewozu, odbiorca wyznacza osobę trzecią to tę osobę uważa się za odbiorcę w rozumieniu $A D R$.
W jednostce transportowej, w zależności od szczegółowych wymagań, powinny być przewożone następujące dokumenty:

1) Dokument przewozowy zawierający wszystkie przewożone towary niebezpieczne,

2) Instrukcje pisemne dla członków załogi,

3) Certyfikat pakowania kontenera lub pojazdu,

4) Zaświadczenie ADR o przeszkoleniu kierowcy,

5) Dokumenty tożsamości ze zdjęciem wszystkich członków załogi pojazdu,

6) Świadectwo dopuszczenia pojazdu do przewozu niektórych towarów niebezpiecznych,

7) Dokumenty wymagane na podstawie innych niż ADR przepisów.

Umowa ADR precyzuje przewóz towarów niebezpiecznych w sztukach przesyłki, luzem oraz w cysternach.

Każda sztuka przesyłki powinna być oznakowana w sposób czytelny i trwały numerami rozpoznawczymi zawartych w niej towarów niebezpiecznych, poprzedzonymi literami UN.

O ile przepisy szczególne nie stanowią inaczej, na sztuce przesyłki zawierającej materiał lub przedmiot niebezpieczny powinny być umieszczone nalepki odpowiadające klasie, do której należy towar. Przykładowe nalepki ostrzegawcze dla różnych klas towarów niebezpiecznych przedstawia (rys.5).

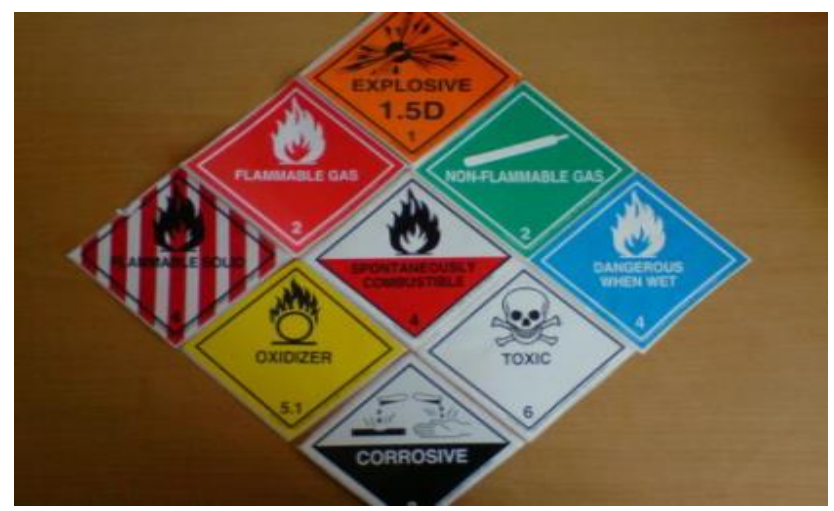

Rys. 5. Przykładowe nalepki ostrzegawcze dla różnych klas towarów niebezpiecznych: klasa 1 (materiały i przedmioty wybuchowe), klasa 2 (gazy), klasa 4.1 (materiały zapalne stałe, materiały samoreaktywne, materiały polimeryzujące i materiały wybuchowe odczulone stałe, klasa 4.2 (materiały podatne na samozapalenie), klasa 4.3 (materiały wytwarzające w zetknięciu z wodą gazy palne), klasa 5.1 (materiały utleniające), klasa 6.1 (materiały trujące), klasa 8 (materiały żrące).

Źródło: umowa $A D R$ [4]

Za wyjątkiem nalepek, które umieszczane są na niecylindrycznej części butli z gazem tj. na szyjce, charakteryzujących się zmniejszonymi wymiarami, każda nalepka powinna być:

- umieszczona na tej samej stronie sztuki przesyłki, o ile pozwala na to wielkość tej sztuki przesyłki, a w przypadku klas 1 i 7 blisko napisu określającego prawidłową nazwę przewozową,

- umieszczona w taki sposób na sztuce przesyłki, aby nie była zakryta lub zasłonięta przez jakąkolwiek część wyposażenia tej sztuki przesyłki, inną nalepką lub oznakowaniem,

- umieszczona w pobliżu innych nalepek, jeżeli wymaga się więcej niż jednej nalepki.

Przykładowe oznakowanie sztuki przesyłki przedstawia rys. 6 .

\section{AUTOBUSY 6/2018}


a)

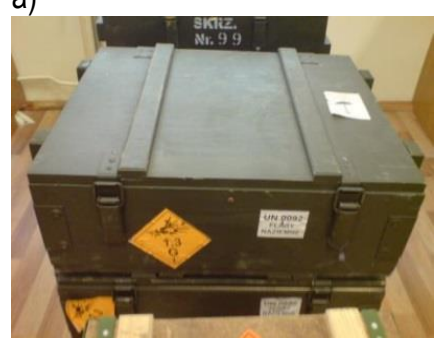

b)

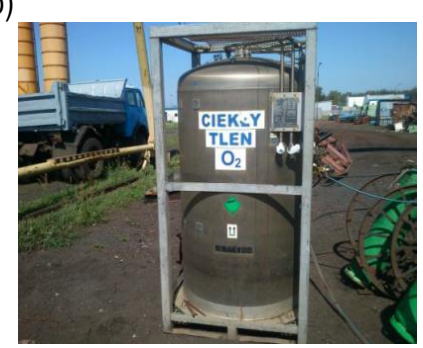

Rys. 6. Przykładowy sposób oznakowania sztuki przesyłki nalepkami ostrzegawczymi: a) sztuka przesyłki klasy 1 (podklasa 1.3 materiał stwarzający zagrożenie pożarem, grupa zgodności Gmateriał pirotechniczny), b) sztuka przesyłki klasy 2 (gaz niepalny, nietrujący).

Źródło: zasoby własne

Opakowanie zbiorcze (rys.7) powinno być:

- oznakowane napisem „OPAKOWANIE ZBIORCZE”,

- numerem UN poprzedzonym literami „UN”,

- nalepkami ostrzegawczymi,

- znakiem dla materiałów zagrażajacych środowisku, jeżeli jest to wymagane, obejmujących każdy towar niebezpieczny znajdujacy się w opakowaniu zbiorczym.

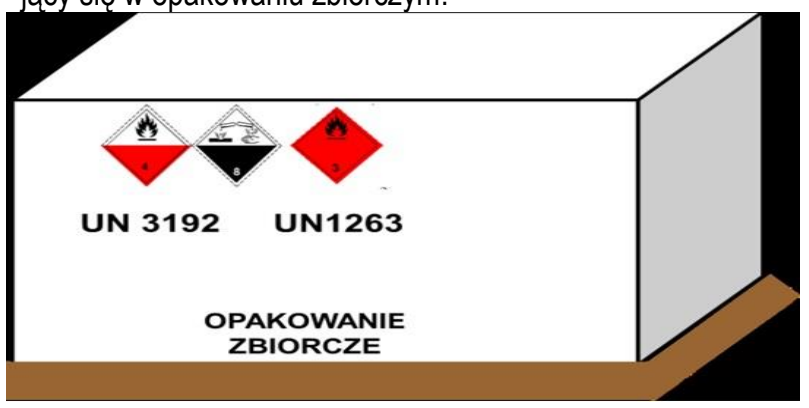

Rys. 7. Przykładowy sposób oznakowania opakowania zbiorczego Żródło: opracowanie własne

Umowa ADR precyzuje również wymagania konstrukcyjne, które muszą być spełnione dla pojazdów w zależności od rodzaju i ilości przewożonego towaru niebezpiecznego. Pojazdami wykorzystywanymi w przewozie towarów niebezpiecznych są pojazdy: EX/II,

\section{EX/III, MEMU, FL i AT.}

Przewóz towarów niebezpiecznych pojazdami należącymi do Sił Zbrojnych został uregulowany rozporządzeniami Ministra Obrony Narodowej $[10,11]$ oraz stosownymi instrukcjami branżowymi.

Przykładowo pojazdami przeznaczonymi do przewozu towarów niebezpiecznych klasy 1 sa pojazdy EX/II oraz EX/III.

Pojazd EX/II jest to pojazd zamknięty lub kryty, napędzany silnikiem wysokoprężnym. Pojazd ten powinien być tak zaprojektowany, zbudowany i wyposażony, aby przewożone materiały wybuchowe były zabezpieczone przed zagrożeniami zewnętrznymi i warunkami atmosferycznymi. Pojazdy te powinny być zamknięte albo kryte opończą wykonaną z materiału odpornego na rozdarcie, nieprzepuszczalnego i trudno zapalnego. Opończa powinna być napięta w ten sposób, aby zakrywała skrzynię ładunkowa ze wszystkich stron. Wszystkie otwory przedziału ładunkowego w pojeździe zamkniętym powinny być wyposażone w zamykane, szczelne drzwi lub pokrywy. Kabina kierowcy powinna być oddzielona pełna ściana od przedziału ładunkowego.

Pojazd EX/III jest to pojazd zamknięty (furgon), napędzany silnikiem wysokoprężnym. Pojazd ten powinien być tak zaprojektowany, zbudowany i wyposażony, aby przewożone materiały wybuchowe były zabezpieczone przed zagrożeniami zewnętrznymi i warunkami atmosferycznymi. Nadwozie powinno być wykonane z materia- łu o minimalnej grubości 10mm., odpornego na ciepło i ogień. Wszystkie drzwi powinny być wyposażone w zamki oraz tak umiejscowione i zbudowane, aby ich łączenia były zakryte. Wszystkie otwory przedziału ładunkowego w pojeździe zamkniętym powinny być wyposażone w zamykane, szczelne drzwi lub pokrywy. Kabina kierowcy powinna być oddzielona pełna ścianą od przedziału ładunkowego. Podłoga przedziału ładunkowego powinna stanowić jednolitą powierzchnię ze ścianą czołowa (bez szczelin).

Przykładowe rodzaje pojazdów do przewozu materiałów i przedmiotów wybuchowych w klasie 1 przedstawia rys. 8. a)

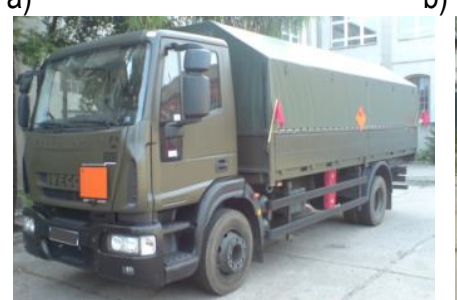

b)

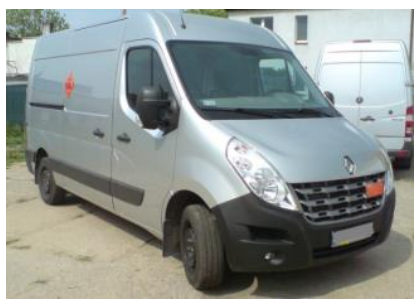

Rys. 8. Przykłady pojazdów wojskowych do transportu towarów niebezpiecznych klasy 1: a) pojazd EX II, b) pojazd EX III Żródło: zasoby własne

Dopuszczalną masę netto $(\mathrm{kg})$ materiałów klasy 1 przypadająca na jednostkę transportową przedstawia tabela 1.

Tab. 1. Dopuszczalna masa netto $w$ kg dla klasy 1 przypadająca na jednostkę transportową.

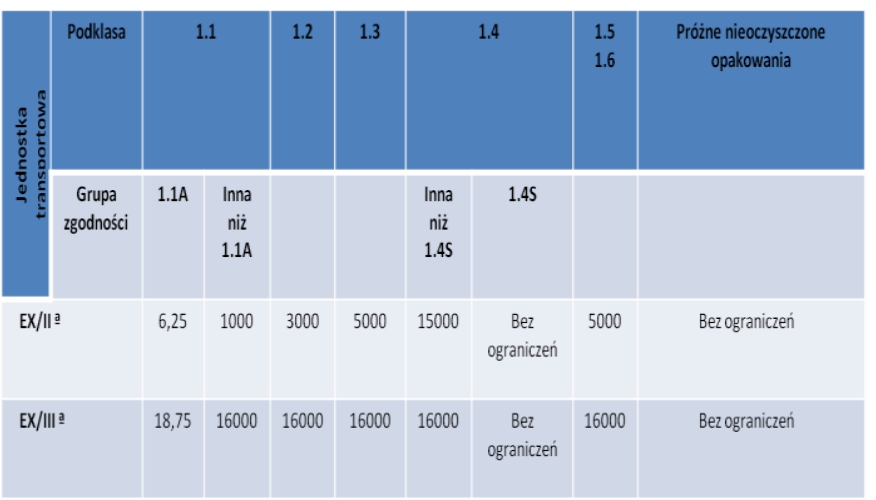

${ }^{a}$ w odniesieniu do opisu pojazdów EX/II i EX/III (część 9 Umowy ADR).

Żródło: umowa ADR [4]

Jednostki transportowe przewożace towary niebezpieczne $\mathrm{w}$ ilościach wyższych niż wskazano w wyłączeniach, powinny być oznakowane tablicami barwy pomarańczowej, a także, jeżeli jest to wymagane nalepkami ostrzegawczymi i znakami zgodnie $z$ istniejacymi międzynarodowymi przepisami.

Pojazdy przewożace towary niebezpieczne, powinny być zaopatrzone $w$ dwie prostokątne tablice barwy pomarańczowej. Jedna $z$ nich powinna być przymocowana z przodu, a druga z tyłu jednostki transportowej, obie prostopadle do jej osi podłużnej. Tablice te powinny być dobrze widoczne. Tablice barwy pomarańczowej powinny mieć charakterystyczne właściwości odblaskowe, szerokość $400 \mathrm{~mm}$ i wysokość $300 \mathrm{~mm}$; powinny być również otoczone czarnym obrzeżem o szerokości $15 \mathrm{~mm}$. Materiały z których wykonano tablicę powinny być odporne na warunki atmosferyczne i zapewniać trwałość oznakowania.

Oznakowania cysterny do przewozu towarów niebezpiecznych w Siłach Zbrojnych przedstawia rys. 9. 
a)

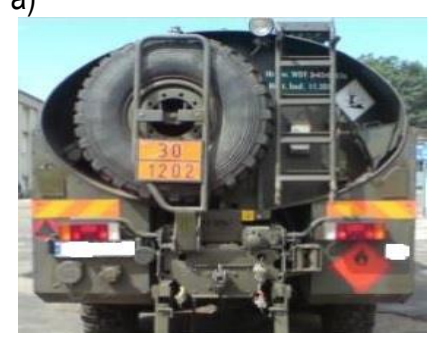

b)

Rys. 9. Oznakowanie pojazdu cysterny tablicami pomarańczowymi i nalepkami ostrzegawczymi: a) tył pojazdu, b) przód pojazdu Źródło: zasoby własne

Niezależnie od wyposażenia wymaganego w ustawie Prawo o ruchu drogowym [2], jednostki transportowe przewożące towary niebezpieczne powinny być wyposażone w wyposażenie przeciwpożarowe (gaśnice do gaszenia grup pożarów $A, B, C$ ) (rys.10) oraz wyposażenie dodatkowe. W każdej jednostce transportowej musi się znajdować co najmniej jedna gaśnica przenośna o minimalnej pojemności $2 \mathrm{~kg}$ proszku gaśniczego do gaszenia silnika, instalacji elektrycznej lub kabiny, oraz dodatkowo gaśnice w zależności od dopuszczalnej masy całkowitej jednostki transportowej.

\begin{tabular}{|c|c|c|c|c|}
\hline $\begin{array}{c}\text { (1) } \\
\text { D.m.c jednostki } \\
\text { transportowej }\end{array}$ & $\begin{array}{c}\text { (2) } \\
\text { Minimalna liczba } \\
\text { gaśnic }\end{array}$ & $\begin{array}{c}(3) \\
\text { Minimalna } \\
\text { calkowita } \\
\text { pojemność na } \\
\text { jednostkę } \\
\text { transportową }\end{array}$ & $\begin{array}{c}(4) \\
\text { Gaśnica do } \\
\text { gaszenia pożaru } \\
\text { silnika lub } \\
\text { kabiny. Co } \\
\text { najmniej jedna o } \\
\text { minimalnej } \\
\text { pojemności: }\end{array}$ & $\begin{array}{c}(5) \\
\text { Wymagana (e) } \\
\text { dodatkowa (e) } \\
\text { gaśnica Co } \\
\text { najmniej jedna } \\
\text { gaśnica powinn } \\
\text { mieć minimalna } \\
\text { pojemność: }\end{array}$ \\
\hline$\leq 3,5$ tony & 2 & $4 \mathrm{~kg}$ & $2 \mathrm{~kg}$ & $2 \mathrm{~kg}$ \\
\hline $\begin{array}{l}3,5 \text { tony } \\
\leq 7,5 \text { tony }\end{array}$ & 2 & $8 \mathrm{~kg}$ & $2 \mathrm{~kg}$ & $6 \mathrm{~kg}$ \\
\hline > 7,5 tony & 2 & $12 \mathrm{~kg}$ & $2 \mathrm{~kg}$ & $6 \mathrm{~kg}$ \\
\hline
\end{tabular}

Rys. 10. Wyposażenie przeciwpożarowe jednostki transportowej Źródło: umowa ADR [4]

Wyposażenie dodatkowe:

- $\quad$ klin pod koła, o odpowiednim rozmiarze w stosunku do dopuszczalnej masy całkowitej pojazdu;

- dwa stojące znaki ostrzegawcze (np. pachołki odblaskowe, trójkaty odblaskowe lub lampy błyskowe o świetle barwy pomarańczowej, zasilane niezależnie od instalacji elektrycznej pojazdu);

- płyn do płukania oczu, który nie jest wymagany dla materiałów wybuchowych oraz gazów;

- kamizelka ostrzegawcza;

- przenośne urządzenie oświetleniowe (latarka);

- para rękawic ochronnych;

- ochrona oczu.

Pojazdy przewożące towary niebezpieczne przejeżdżając przez miejscowości, nie powinny przekraczać prędkości $50 \mathrm{~km} / \mathrm{h}$, pomimo dozwolonych wyższych prędkości na danym odcinku drogi.

Obowiazujace w Polsce, okresowe zakazy ruchu pojazdów i zespołów pojazdów o d.m.c. przekraczajaccej 12 ton, np. w dni świąteczne i weekendy, nie dotyczą pojazdów przewożących towary niebezpieczne, dla których wymagane jest oznakowanie tablicami barwy pomarańczowej.

Warunki przejazdu, realizowane są zgodnie z danymi zawartymi w zezwoleniu na przejazd drogowy i przepisami ruchu drogowego obowiazującymi na trasie przejazdu.

Obowiazkowi uzyskania zezwolenia nie podlegają przejazdy pojazdów Sił Zbrojnych:
- przewożących towary niebezpieczne klasy 1, po drogach publicznych w rejonie ośrodków szkolenia poligonowego lub garnizonu, wykonywane pojazdami wojskowymi oraz cywilnymi środkami transportu do przewozów wojskowych w celu realizacji zajęć programowych;

- przewożacych towary niebezpieczne w okresie stanu wyjątkowego, stanu klęski żywiołowej, a także w czasie prowadzenia akcji ratowniczej lub akcji związanej z przywracaniem bezpieczeństwa i porządku publicznego;

używanych do prowadzenia akcji ratowniczej posiadających na wyposażeniu urządzenia zawierające towary niebezpieczne.

\section{ZASADY PORUSZANIA SIE TRANSPORTÓW WOJSKOWYCH $Z$ ŁADUNKAMI NIEBEZPIECZNYMI I TRANSPORTÓW PONADGABARYTOWYCH}

Ruch transportów wojskowych (pojazdów ponadnormatywnych, pojazdów przewożących towary niebezpieczne) po terytorium RP podlega ciagłemu nadzorowaniu, monitoringowi i koordynacji przez odpowiednie do tego powołane krajowe organy transportowe i służby dyżurne (dyspozytorskie) wojskowe i cywilne. Zadaniem tych organów jest czuwanie nad bezpieczeństwem przewozów.

W sytuacjach zagrażających bezpieczeństwu publicznemu podejmuja one stosowne decyzje do wstrzymania przemieszczenia pojazdów włącznie.

W planowaniu przewozów transportem drogowym szczególną rolę odgrywa wydawanie pozwoleń na przejazd dla pojazdów nienormatywnych i przewożących towary niebezpieczne. Zezwolenie na przejazd drogowy wydaje się na jednorazowy przejazd. W obecnych czasach obserwuje się wzrost ilości pojazdów przewożących towary niebezpieczne i pojazdów nienormatywnych.

Pozwolenie na przejazd drogowy wymagane jest w następujacych przypadkach przejazdów dla [1]:

g) pojazdów nienormatywnych,

h) pojazdów przewożących towary niebezpieczne,

i) kolumn pojazdów w składzie sześć pojazdów i więcej.

Podstawą do otrzymania pozwolenia na przejazd jest złożenie zapotrzebowania do organów wojskowych w terminach w zależności od rodzaju przemieszczenia na terytorium kraju lub w zwiąku z przejazdem międzynarodowym.

Zezwolenie na przejazd drogowy wydawane jest (licząc od dnia wpływu) w następujących terminach [1]:

1. Nie później niż $\mathbf{3 0}$ dni

- w przypadku przejazdu drogowego poza granice kraju.

2. Nie później niż $\mathbf{5}$ dni roboczych

- w przypadku krajowego przejazdu drogowego pojazdów nienormatywnych.

3. Nie później niż 3 dni robocze

- w przypadku krajowego przejazdu drogowego pojazdów nienormatywnych Sojuszniczych Sił Wysokiej Gotowości, po wyznaczonych wcześniej trasach przemieszczenia.

4. Nie później niż 3 dni robocze

- w przypadku krajowego przejazdu drogowego kolumn pojazdów i pojazdów przewożących towary niebezpieczne.

5. Nie później niż 3 dni robocze

- w stanie gotowości obronnej państwa czasu kryzysu i wojny.

Każdy przewóz towarów niebezpiecznych oraz przejazd pojazdów nienormatywnych, na które uzyskano i wydano pozwolenie, jest zgłaszany przez właściwe komórki transportu i ruchu wojsk organom Żandarmerii Wojskowej, które to zabezpieczaja taki przejazd na terenie RP.

\section{AUTOBUSY 6/2018}


Aby zapewnić bezpieczny i sprawny przejazd przez tereny zabudowane, wykorzystuje się również inne mobilne elementy regulacji ruchu w postaci pododdziałów regulacji ruchu lub policji, które pełnia rolę pilota.

\section{PRZEWOZY ŁADUNKÓW TRANSPORTEM SAMOCHODOWYM W 2016 ROKU.}

Na podstawie opracowania Głównego Urzędu Statystycznego [15] przewozy ładunków transportem samochodowym ogółem w 2016 roku (w milionach tonokilometrów) kształtowały się na poziomie 303560 , natomiast przewozy ładunków transportem samochodowym (w tysiącach ton) wynosiły 1546572 . Średnia odległość ogółem przewozu 1 tony ładunku wyniosła $196 \mathrm{~km}$. Biorąc pod uwage analize do roku 2015, nastapił wzrost przewozu w tysiącach ton o 2,7\%, natomiast przewóz w milionach tonokilometrów odnotował wzrost o $11,2 \%$. Dla przykładu, zgodnie z opracowaniem GUS [16] według grup ładunków, przewieziono w 216 roku, ciekłe produkty rafinacji ropy naftowej w wielkości 31064 tysięcy ton, a chemikalii i produktów chemicznych 65669 tysięcy ton, co również było wzrostem o $7 \%$ w stosunku do 2015 r. Natomiast sprzętu transportowego przewieziono 32071 tysięcy ton, wzrost o 48,8\%.

Rozpatrując ładunki masowe ciekłe i stałe przewożone luzem, w 2016 roku przewieziono: ładunki masowe ciekłe luzem w ilości 73938 tys. ton, ładunki masowe stałe luzem w ilości 609824 tyś. ton. Przewieziono transportem drogowym: kontenery wielkie 12593 tys. ton, ładunki na paletach w ilości 295374 tyś. ton.

Charakterystyka przewiezionych ładunków w analizie statystycznej została również ujęta na podstawie zastosowanego środka transportu. Dla przykładu przewieziono z wykorzystaniem cystern i pojemników 105188 tyś. ton ładunku, a z wykorzystaniem środków transportu do przewozu kontenerów 25794 tyś. ton ładunku. Transportem uniwersalnym przewieziono 460097 tyś ton ładunku.

Biorąc pod uwage transport wojskowy, przewóz ładunków kształtuje się na poziomie $0,5 \% \mathrm{w}$ stosunku do transportu samochodowego cywilnego.

\section{PODSUMOWANIE}

Jednym z elementów wpływających na bezpieczeństwo na drogach publicznych jest bezpieczny przewóz towarów niebezpiecznych oraz ładunków ponadgabarytowych. Przewoźnicy przewożący tego rodzaju towary i ładunki musza stosować się do ogólnych przepisów o ruchu drogowym oraz zasad bezpieczeństwa dotyczących przewozu towarów niebezpiecznych zawartych w umowie ADR. Należy również pamiętać o organizacji samego procesu przewozowego, czyli załadunku, przeładunku i rozładunku towarów i ładunków. Tyczy się to zarówno załadunku ładunków ponadgabarytowych, jak również napełniania lub opróżniania cysterny i przekazania jej w stanie opróżnionym przewoźnikowi. Prawidłowo przeprowadzony proces przewozowy przyczyni się do zapewnienia bezpieczeństwa dla użytkowników dróg i środowiska naturalnego. Oznakowania pojazdów przewożących towary niebezpieczne oraz oznakowania i sygnalizacja pojazdów ponadgabarytowych jest ważna informacja dla innych uczestników ruchu. Kierowcy pojazdów napotykajacy na drodze pojazd oznakowany tablicami pomarańczowymi powinni zachować szczególną ostrożność. Kierowcy powinni mieć świadomość , że kolizja z takim pojazdem może mieć niewyobrażalne skutki w postaci zatrucia środowiska naturalnego, strat materialnych oraz śmierci wielu osób.

W przewozach ponadgabarytowych oraz $w$ transporcie towarów niebezpiecznych decydującą rolę odgrywa prawidłowo zaplanowany i przeprowadzony przewóz ładunków. Bardzo ważnym zagadnieniem jest prawidłowy dobór środka transportu dla ładunków ponadgabarytowych oraz towarów niebezpiecznych. Nieodpowiednio dobrany środek transportu może przyczynić się do powstania wypadku na drodze. Pełne bezpieczeństwo zagwarantuje prawidłowe zamocowanie ładunków na pojeździe, a także w przypadku towarów niebezpiecznych przewóz zgodnie z zasadami ładowania razem towarów niebezpiecznych oraz ze stopniami napełnienia cystern, a także dużych pojemników do przewozu luzem. Dużą rolę odgrywa również pilotowanie pojazdów, które wpływa na poprawę bezpieczeństwa w czasie przewozu ładunków. Prawidłowo oznakowany ładunek i pojazd (tablicami ostrzegawczymi i nalepkami ostrzegawczymi) będzie widoczny przez innych uczestników ruchu z dużej odległości.

W przewozach najważniejszą rolę odgrywają przewoźnicy, kierowcy, którzy w największym stopniu mają wpływ na bezpieczeństwo procesu przewozowego. Do ich obowiązków należy przyjęcie ładunku do przewozu zgodnie z dokumentacją nadawcy, a także stały monitoring ładunku w czasie przewozu. W obecnych czasach brak nadzoru nad pojazdem, może skutkować kradzieżą pojazdu i wykorzystaniem go w aktach terrorystycznych. Ważną więc kwestia jest stały nadzór nad pojazdami przewożącymi towary wysokiego ryzyka. Kierowcy oraz członkowie załogi powinni być przeszkoleni w zakresie ochrony ładunków niebezpiecznych wysokiego ryzyka oraz znać zasady przechowywania i postoju pojazdu przewożącego ww. rodzaj towaru. W przewozach ponadgabarytowych oraz towarów niebezpiecznych bardzo ważne są również zasady przewozu przez tunele. W przypadku oznakowań tuneli przez które nie można przejechać, należy wybrać trasę alternatywną. Bezpieczeństwo na drodze gwarantuje również zachowanie bezpiecznych prędkości oraz zachowanie bezpieczeństwa podczas niesprzyjających warunków atmosferycznych. Kierowcy przy takiego rodzaju przewozach powinni mieć odpowiednie kwalifikacje oraz doświadczenie.

Przewozy ładunków ponadgabarytowych oraz towarów niebezpiecznych powinny odbywać się zgodnie z otrzymanym zezwoleniem od władz wydających takie zezwolenia, a także zgodnie z określona trasą przewozu. Zabronione jest skracanie trasy lub przejazd inną drogą według uznania kierowcy.

\section{BIBLIOGRAFIA}

1. Zasady Wojskowego Ruchu Drogowego - DU.4.4.4 B, sygn. MON DGRSZ, Szef. Kom. 189/2015,

2. Ustawa z dnia 20 czerwca 1997 r. Prawo o ruchu drogowym (Dz. U. z 2017 r. poz. 1260, z późn. zm.)

3. Ustawa z dnia 19 sierpnia 2011 r. o przewozie towarów niebezpiecznych (Dz. U. z 2016 r. poz. 1834 z późn. zm.),

4. Umowa Europejska o przewozie drogowym towarów niebezpiecznych - ADR (Dz. U. z 2015 r. poz. 882 z późn. zm.),

5. Rozporządzenie Ministra Transportu, Budownictwa i Gospodarki Morskiej z dnia 23 maja 2012 r. w sprawie pilotowania pojazdów nienormatywnych,

6. Rozporządzenie Ministra Obrony Narodowej oraz Spraw Wewnętrznych i Administracji z 9 czerwca 2005 r. w sprawie warunków technicznych pojazdów specjalnych i pojazdów używanych do celów specjalnych Sił Zbrojnych RP (Dz. U. z 2005 r. poz. 974),

7. Rozporządzenie Ministra Obrony Narodowej oraz Spraw Wewnętrznych i Administracji z 24 czerwca 2016 r. w sprawie warunków technicznych pojazdów specjalnych i pojazdów używanych do celów specjalnych Sił Zbrojnych RP (Dz. U. z 2016 r. poz. 1027),

8. Rozporządzenie Ministra Obrony Narodowej z dnia 9 listopada 2012 r. w sprawie warunków krajowego przewozu towarów nie- 
bezpiecznych środkami transportu należącymi do Sił Zbrojnych $R P$ lub środkami transportu, za które Siły Zbrojne $R P$ są odpowiedzialne (Dz. U. z 2012 r. poz. 1364),

9. Rozporządzenie Ministra Obrony Narodowej z dnia 11 marca 2016 r. w sprawie wydawania zezwoleń wojskowych na przejazd drogowy pojazdów przewożących towary niebezpieczne (Dz. U. Z 2016 r. poz. 362),

10. Rozporządzenie Ministra Spraw Wewnętrznych i Administracji z dnia 6 lipca 2010 r. w sprawie kierowania ruchem drogowym (Dz. U. z 2016 r. poz. 143),

11. Rozporządzenie Ministra Obrony Narodowej z dnia 6 kwietnia 2017 r. w sprawie sposobu i trybu wydawania zezwoleń wojskowych na przejazd drogowy oraz sposobu organizacji i oznakowania kolumn pojazdów Sił Zbrojnych Rzeczypospolitej Polskiej (Dz. U. z 2017 r. poz. 809),

12. Rozporządzenie Ministra Obrony Narodowej z dnia 21 listopada 2012r. w sprawie sposobu i trybu wydawania zezwoleń wojskowych na przejazd drogowy oraz sposobu organizacji i oznakowania kolumn pojazdów SZRP (Dz.U poz. 1368 z dnia 6 grudnia $2012 r$.),

13. Rozporządzenie Ministra Obrony Narodowej z dnia 29 sierpnia 2017 r. w sprawie kontroli ruchu drogowego i kierowania tym ru- chem przez wojskowe organy porządkowe oraz warunków i trybu współdziałania Żandarmerii Wojskowej z Policją w prowadzeniu ewidencji kierowców naruszających przepisy ruchu drogowego (Dz. U. z 2017 r. poz. 1730),

14. Ustawa o drogach publicznych z 21.03.1985 r. (Dz.U. 2017 poz. 2222 z późn. zm.).

15. Opracowanie GUS z dnia 30.05.2017r. w sprawie przewozu ładunków i pasażerów w 2016 roku.

16. Opracowanie GUS z lipiec 2017r.- Transport, wyniki działalności w 2016 roku.

17. www.gddkia.gov.pl

Autorzy:

mgr inż. Wojciech Puszkiewicz - Państwowa Wyższa Szkoła Zawodowa w Pile, Instytut Politechniczny, Zakład Transportu.

dr hab. inż. Piotr Piątkowski, prof. PK, prodziekan ds. Studenckich - Politechnika Koszalińska, Zakład Transportu, Wydział Mechaniczny.

JEL: 018 DOI: 10.24136/atest.2018.238

Data zgłoszenia: 2018.05.28 Data akceptacji: 2018.06.15 